\title{
The ISO 9000 Certification: Little Pain, Big Gain?
}

\author{
Beata Javorcik* and Naotaka Sawada ${ }^{*}$
}

forthcoming in the European Economic Review

\begin{abstract}
This paper examines the effect of obtaining an ISO 9000 certification on various aspects of business performance using firm-level panel data from Slovenia covering the period 1987-2006. To control for the possible endogeneity of obtaining the certification propensity score matching is combined with a difference-in-differences approach. The results indicate that an ISO 9000 certification boost the certified firm's sales, exports and employment. It also has a positive effect on profits, profitability ratio, labor productivity and wages, though these effects appear with a delay and the latter two are less robust.
\end{abstract}

Keywords: ISO 9000, management, firm performance

JEL classification: M10, M31, F16, J31, O52

\section{Introduction}

Until recently the quality of management practices has not received much attention in the economics profession. Yet, management matters. Management heterogeneity can explain a significant amount of variation in investment, financial, and organizational practices of firms (Bertrand and Schoar 2003). Measures of managerial practice are strongly associated with firm-level productivity, profitability, Tobin's Q, and survival rates. Management practices also display significant cross-country differences

\footnotetext{
* University of Oxford and CEPR, Department of Economics, Manor Road Building, Manor Road, Oxford OX1 3UQ, United Kingdom. Email: beata.javorcik@economics.ox.ac.uk.

- Retired. No affiliation.
} 
and significant within-country differences (Bloom and Van Reenen 2007; 2010). Improvements in management practices translate into better performance within months (Bloom et al. 2013).

Given that better management leads to better firm-level outcomes, how can firms improve their management practices? This study argues that obtaining an ISO certification offers a route to better management. It is also likely to reduce information asymmetries between business partners. We investigate this issue in the context of Slovenia, which due to its socialist legacy found itself lagging in term of management practices at the beginning of its transition process (Svejnar 2002). Slovenia has made tremendous progress in reforming its economy and in March 2004 became the first transition country to graduate from a borrower status to a donor partner at the World Bank. If ISO certifications really lead to better outcomes, the effect should be more pronounced in Slovenia than in industrialized countries.

The International Organization for Standardization (ISO) 9000 series of quality management system has seen a spectacular increase in its popularity during the past two decades. The number of certifications increased more than 20 fold from 46,571 in 1993 to 1,109,905 as of the end of 2010 (ISO 2011). The certification process aims to improve performance of certified firms by helping their managers follow eight principles: customer focus, leadership, involvement of people, process approach, system approach to management, continual improvement, factual approach to decision making, and mutual beneficial supplier relationships. ${ }^{1}$ Surveys of certified firms suggest that expected boosts to profits, process improvements and marketing benefits are the key drivers behind certification applications (Buttle 1997). There exists a large body of anecdotal, survey and econometric results suggesting that certified firms

\footnotetext{
${ }^{1}$ See the ISO home page, quality management practices, http://www.iso.org/iso/qmp, and the standards, ISO 9000:2005 and ISO 9004: 2000.

The purpose of the ISO 9000 quality standards is to ensure consistent quality of production rather than production of high quality products (see Arora and Asundi 1999). Its philosophy can be described as "document what you do, do what you document, and verify that you are doing it" (unnamed manager quoted in Cole 1999: 156).
} 
perform better, but the existing evidence cannot prove causality in a convincing way across a range of sectors. $^{2}$

To assess the effect of ISO certification on firm performance, our analysis combines propensity score matching with a difference-and-differences approach. Matching is done within industry-year cells. We use information on 38,495 Slovenian firms, 668 of which obtained an ISO certification during the period covered by our data. Of these, 234 firms are observed at least a year prior to as well as four years after the certification thus lending themselves to our empirical exercise. The analysis indicates that better performers (larger and more profitable firms as well as exporters) are more likely to obtain an ISO certification. More interestingly, our results are consistent with ISO 9000 certifications leading to an improved firm performance in terms of sales, exports, labor productivity and profits. While the effects on the former variables materialize very quickly, the boost to labor productivity and profits seems to take place with a delay. We also find that certified firms experience greater employment and real wage increases relative to the control group, though the wage effect is less robust.

The results of our analysis suggest that the quality of management practices matters. The view, while obvious to business practitioners, until recently has received little support in the economics profession. Our results further suggest that international certification standards are an effective mechanism for transferring best management practices to emerging markets and developing countries which for various reasons may lag in this area.

\footnotetext{
${ }^{2}$ In an unpublished study, Arora and Asundi (1999) focus on 95 Indian software firms and conclude that an ISO certification serves as a signal to potential customers and leads to a modest increase in employment growth. The authors instrument for the endogeneity of the decision to obtain a certification using a dummy for firms established prior to 1992 and a dummy for publicly traded firms. Corbett et al. (2005) apply the event study approach to the data on ISO 9000 certified US manufacturing firms observed between 1987 and 1997 to analyze the impact of the certifications on financial performance. They find that three years after certification the certified firms display better performance in terms of the return on assets and that better performing firms are more likely to get certified. Terlaak and King (2006) show that ISO certified firms in the US grow faster after obtaining a certification. The authors do not explicitly address the endogeneity problem, though in a robustness check they show that adjusting for the average growth rate in the same industry does not affect the results.
} 
This paper is structured as follows: The next section provides a brief overview of the ISO 9000 certification. Section 3 describes the data used and presents some exploratory results. The main empirical analysis on the impact of ISO certification on various performance indicators is contained in Section 4. Conclusions are presented in the last section.

\section{Overview of ISO 9000 certifications}

Formalized quality assurance originated in response to the needs of the defense industry for standards but later spread beyond the military giving rise to various national standards. In 1987, the British government persuaded the International Organization for Standardization (ISO) to adapt British Standards (BS) 5760 as an international standard. BS 5760 was developed as a management standard that specified how the manufacturing process was to be conducted, rather than what to manufacture. The ISO 9000 standard was revised 1994 to emphasize quality assurance through preventive actions, instead of checking just the final product, reflecting Japanese approach of total quality management. The 2000 revision of the standard (ISO 9001) placed greater emphasis on management system effectiveness through process performance measures. It also made explicit expectations of continual process improvement and tracking customer satisfaction. A minor amendment to the standard was made in 2008.

The key ideas behind the ISO 9001 standard involve having a formal quality policy, closely linked to the business and marketing plan and customer needs. Employees at all levels are expected to understand and follow the quality policy and to work towards measurable objectives. Decisions about the quality system are based on recorded data. The quality system is regularly audited and evaluated for compliance and effectiveness. Records of how and where raw materials and products are processed are kept to allow products and problems to be traced to the source. There are formalized systems for communicating with customers about product information, inquiries, contracts, orders, feedback and complaints. When new products are being developed, plans for all stages of the development process involve testing and document whether the product meets design requirements, regulatory requirements 
and user needs. The firm performance is regularly reviewed through internal audits to determine whether the quality system is working and what improvements can be made. There are formal procedures for dealing with actual and potential problems involving suppliers, customers or internal issues.

An ISO 9000 certification is awarded by an accredited certification body to a firm or a plant where a quality management system has been established. The award process requires a detailed review and documentation of the firm's production and service processes to ensure they are in accordance with ISO 9000 standard requirements. In order to maintain the status of the certification, the system is reviewed periodically for compliance to the ISO 9000 standards by certified auditors. Every three years, the certification must be renewed with a full audit.

ISO 9000 standards play a central role in diffusing knowledge in those industries, where products and processes supplied by various providers must interact with one another. The adoption of international standards through ISO certification may create productivity benefits going beyond the transfer of new productivity-enhancing knowledge embodied in standards. Obtaining an ISO certification may boost the ability of its recipient to enter global supply chains and thus benefit from economies of scale and transfer of technical and organizational knowledge from technologically advanced buyers, usually multinational corporations.

Firms invest in an ISO certification in order to improve their chances in tenders, obtain a preferred supplier status, enhance customer satisfaction and increase profitability. For instance, 17 percent of Czech companies surveyed by the World Bank reported getting a quality certification (e.g., ISO 9000) in order to become suppliers to multinationals. These firms constituted 40 percent of all companies reporting having such a certification (Javorcik and Spatareanu 2009). Thus, an ISO 9000 certification can have three types of impact on its recipient: (i) a reputational effect, which may be particularly important to smaller firms or firm from countries (such as Slovenia) which traditionally have not served as suppliers to global businesses, (ii) improvements to performance (direct channel) resulting directly 
from making the firm compliant with the ISO 9000 requirement; (iii) improvements to performance (indirect channel) resulting from doing business with world class companies, where these new business relationships were facilitated by obtaining an ISO certification. ${ }^{3}$

\section{Data and Exploratory Analysis}

\subsection{Data}

Our data set was provided by the Slovenian Statistical Office. It includes information on 38,495 firms active in manufacturing and services industries. The data base contains company accounts, including profit and loss statements and balance sheets from 1987 to 2006. All figures are expressed in real terms using industry-specific producer price indices obtained from the Slovenian Statistical Office. ${ }^{4}$

Information on holders of ISO certifications and the year of the award was obtained from ISO accredited certification institutions in Slovenia: Slovenian Institute of Quality and Metrology (SIQ); Bureau Veritas (BVQI); TÜV Management Service GmbH; and British Standards Institute (BSI). There are 668 certified firms in our database which corresponds to 80 percent of certified firms in Slovenia. Summary statistics are presented in Appendix Table A1.

\subsection{Exploratory estimation}

We take the first look at the data by estimating a naïve OLS regression:

$$
\ln \left(\text { Outcome }_{i s t}\right)=\alpha+\beta_{1} \text { Firm certified }_{\text {ist }}\left(+\beta_{2} \text { Firm will be certified within } 3 \text { yrs }_{i s t}\right)+\varepsilon_{\text {ist }}
$$

where the dependent variable represents various outcomes related to firm $i$ observed in year $t$; Firm certified is an indicator variable equal to one if firm $i$ holds an ISO certification in year $t$, and zero

\footnotetext{
${ }^{3}$ See the literature documenting productivity spillovers from multinationals to their suppliers (Javorcik 2004, Javorcik and Spatareanu 2008 and 2009b; Blalock and Gertler 2008) and the literature providing evidence on learning through exporting (van Biesebroeck 2005; De Loecker 2007).

${ }^{4} 2000$ is the base year.
} 
otherwise; Firm will certified within 3 yrs is another indicator taking on the value of 1 if firm $i$ does not hold an ISO certification in year $t$ but will obtain one in year $t+1, t+2$ or $t+3$. The indicator takes on a value of zero for firms that already have a certification and for firms that do not have a certification and will not receive one within the three-year timeframe.

As evident from Panel A of Table 1 below, firms holding an ISO certification outperform other firms in terms of all the criteria considered. They are much larger in terms of sales and employment, they are more likely to export and tend to have a higher volume of exports, they enjoy higher profitability and labor productivity and tend to pay higher wages. All of these estimates are statistically significant at the one percent level.

The results from Panel B indicate that better performers self-select into obtaining ISO certifications. Put differently, firms that will be awarded an ISO certification within the next three years already enjoy a premium in terms of size, exports, profitability, productivity and average wage. Interestingly, obtaining a certification helps firms boost this advantage, as the premium associated with having a certification is larger than the premium enjoyed by future certification holders. All of these estimates are statistically significant at the one percent level, and the difference between the two coefficients is statistically significant in all cases except for labor productivity and profitability (profits/sales).

One may be concerned that the results so far are driven by ISO certifications being more prevalent in export-oriented industries or industries with a larger minimum efficient scale of production. Therefore, we add (2-digit NACE) industry-year fixed effects $\left(\alpha_{\mathrm{st}}\right)$ so that we compare certified firms to other firm operating in the same industry in the same year. Our empirical specification now becomes:

$\ln \left(\right.$ Outcome $\left._{\text {ist }}\right)=\theta_{1}$ Firm certified $_{\text {ist }}\left(+\theta_{2}\right.$ Firm will be certified within 3 yrs $\left._{\text {ist }}\right)+\alpha_{s t}+\epsilon_{\text {ist }}(2)$

The results, presented in Panels $\mathrm{C}$ and $\mathrm{D}$, indeed suggest that certified firms are not uniformly distributed across industries. Making comparisons within-industry-year cells leads to a slight decline in the magnitude of the estimates, which nevertheless remain statistically significant at the one percent 
level. The results now suggest self-selection in terms of all variables considered as well as a positive impact of the certification in terms of sales, exports, employment and profits.

In the final exploratory regression, we account for unobservable firm heterogeneity by adding firm fixed effects:

$\ln \left(\right.$ Outcome $\left._{\text {ist }}\right)=\delta_{1}$ Firm certified $_{\text {ist }}\left(+\delta_{2}\right.$ Firm will be certified within 3 yrs $\left._{\text {ist }}\right)+\alpha_{i}+\alpha_{s t}+\epsilon_{\text {ist }}$ (3)

Doing so has a dramatic impact on the results (see Panels E and F). The certification premium remains positive and statistically significant at the one percent level in all but two cases (average wage and labor productivity), but the size of the estimates goes down by an order of magnitude. We take away two messages from these results. First, having a certification seems to boost a firm's performance in a variety of ways. Second, firm characteristics affect the choice of becoming certified and hence addressing the self-selection in a convincing way is of key importance.

Although including firm fixed effects helps capture some factors driving self-selection, this is not a fully convincing approach because our panel spans a period of 20 years and firm characteristics may evolve differently over time and affect the choice of applying for a certification. In the next section we discuss our preferred empirical strategy addressing the selection issue. 
Table 1: First look at the data

\begin{tabular}{|c|c|c|c|c|c|c|c|c|}
\hline & $\ln ($ Sales $)$ & $\begin{array}{c}\text { Exporter } \\
\text { dummy }\end{array}$ & $\ln ($ Exports) & $\begin{array}{c}\ln (\text { Employ- } \\
\text { ment })\end{array}$ & $\begin{array}{c}\ln (\text { Labor } \\
\text { productivity })\end{array}$ & $\begin{array}{l}\ln \text { (Wage bill/ } \\
\text { Employment) }\end{array}$ & $\ln$ (Profits) & $\ln$ (Profit/Sales) \\
\hline \multicolumn{9}{|c|}{ Panel A: OLS } \\
\hline Firm certified & $\begin{array}{c}3.804 * * * \\
(0.044)\end{array}$ & $\begin{array}{c}0.544 * * * \\
(0.009) \\
\end{array}$ & $\begin{array}{c}3.363 * * * \\
(0.055) \\
\end{array}$ & $\begin{array}{c}2.901 * * * \\
(0.022)\end{array}$ & $\begin{array}{c}1.407 * * * \\
(0.078)\end{array}$ & $\begin{array}{c}0.632 * * * \\
(0.021)\end{array}$ & $\begin{array}{c}4.356 * * * \\
(0.152)\end{array}$ & $\begin{array}{c}0.073 * * * \\
(0.007)\end{array}$ \\
\hline \multicolumn{9}{|c|}{ Panel B: OLS } \\
\hline Firm certified & $\begin{array}{c}3.812 * * * \\
(0.044)\end{array}$ & $\begin{array}{c}0.545^{* * *} * \\
(0.009)\end{array}$ & $\begin{array}{c}3.377 * * * \\
(0.055)\end{array}$ & $\begin{array}{c}2.907 * * * \\
(0.022)\end{array}$ & $\begin{array}{c}1.410 * * * \\
(0.078)\end{array}$ & $\begin{array}{c}0.634 * * * \\
(0.021)\end{array}$ & $\begin{array}{c}4.365 * * * \\
(0.151)\end{array}$ & $\begin{array}{c}0.073 * * * \\
(0.007)\end{array}$ \\
\hline Equality test p-value & 0.000 & 0.000 & 0.000 & 0.000 & 0.106 & 0.006 & 0.000 & 0.369 \\
\hline \multicolumn{9}{|c|}{ Panel C: OLS with industry-year FE } \\
\hline Firm certified & $\begin{array}{c}3.339 * * * \\
(0.045)\end{array}$ & $\begin{array}{c}0.421 * * * \\
(0.009)\end{array}$ & $\begin{array}{c}2.748^{* * * *} \\
(0.055)\end{array}$ & $\begin{array}{c}2.503 * * * \\
(0.021)\end{array}$ & $\begin{array}{c}1.086 * * * \\
(0.080)\end{array}$ & $\begin{array}{c}0.486 * * * \\
(0.022)\end{array}$ & $\begin{array}{c}3.733 * * * \\
(0.154)\end{array}$ & $\begin{array}{c}0.058 * * * \\
(0.007)\end{array}$ \\
\hline \multicolumn{9}{|c|}{ Panel D: OLS with industry-year FE } \\
\hline Equality test $\mathrm{p}$-value & 0.000 & 0.000 & 0.000 & 0.000 & 0.408 & 0.900 & 0.019 & 0.619 \\
\hline \multicolumn{9}{|c|}{ Panel E: Firm FE and industry-year FE } \\
\hline Firm certified & $\begin{array}{c}0.277 * * * \\
(0.039)\end{array}$ & $\begin{array}{c}0.038^{* * * *} \\
(0.010)\end{array}$ & $\begin{array}{c}0.254 * * * \\
(0.053)\end{array}$ & $\begin{array}{c}0.129 * * * \\
(0.011)\end{array}$ & $\begin{array}{c}0.161 \\
(0.108)\end{array}$ & $\begin{array}{l}-0.038 \\
(0.026)\end{array}$ & $\begin{array}{c}1.002 * * * \\
(0.223)\end{array}$ & $\begin{array}{c}0.024 * * \\
(0.010)\end{array}$ \\
\hline \multicolumn{9}{|c|}{ Panel F: Firm FE and industry-year FE } \\
\hline Firm certified & $\begin{array}{c}0.280 * * * \\
(0.040)\end{array}$ & $\begin{array}{c}0.040 * * * \\
(0.010)\end{array}$ & $\begin{array}{c}0.246 * * * \\
(0.055)\end{array}$ & $\begin{array}{c}0.130 * * * \\
(0.012)\end{array}$ & $\begin{array}{c}0.142 \\
(0.111)\end{array}$ & $\begin{array}{l}-0.041 \\
(0.027)\end{array}$ & $\begin{array}{c}1.026^{* * * *} \\
(0.229)\end{array}$ & $\begin{array}{c}0.024 * * \\
(0.010)\end{array}$ \\
\hline $\begin{array}{l}\text { Firm will be } \\
\text { certified within } 3 \text { years }\end{array}$ & $\begin{array}{c}0.016 \\
(0.049)\end{array}$ & $\begin{array}{c}0.010 \\
(0.012)\end{array}$ & $\begin{array}{l}-0.0414 \\
(0.069)\end{array}$ & $\begin{array}{c}0.006 \\
(0.014)\end{array}$ & $\begin{array}{l}-0.096 \\
(0.137)\end{array}$ & $\begin{array}{l}-0.016 \\
(0.033)\end{array}$ & $\begin{array}{c}0.124 \\
(0.282)\end{array}$ & $\begin{array}{c}0.002 \\
(0.012)\end{array}$ \\
\hline Equality test $\mathrm{p}$-value & 0.000 & 0.031 & 0.000 & 0.000 & 0.122 & 0.506 & 0.005 & 0.113 \\
\hline
\end{tabular}

Standard errors are presented in parentheses. *, **, *** indicate statistical significance at the 10,5 and $1 \%$ level, respectively. 


\section{Impact of ISO 9000 Certification on Firm Performance: Main Analysis}

\subsection{Econometric strategy}

To assess the effect of an ISO 9000 certification on firm performance (outcome Y), one would like to compare the performance of certified firms to what their performance would have been had they not been certified:

$$
\mathrm{E}\left(\mathrm{Y}_{1}-\left.\mathrm{Y}_{0}\right|_{\mathrm{ISO}=1}\right)=\mathrm{E}\left(\left.\mathrm{Y}_{1}\right|_{\mathrm{ISO}=1}\right)-\mathrm{E}\left(\left.\mathrm{Y}_{0}\right|_{\mathrm{ISO}=1}\right)
$$

For obvious reasons, the latter performance is not observable. We use propensity score matching to construct this missing counterfactual by drawing comparisons conditional on a vector $\boldsymbol{X}$ of observable firm characteristics. The underlying assumption for the validity of the procedure is that conditional on the observable characteristics that are relevant for the certification, the treated (ISO certified enterprises) and non-treated firms (those remaining uncertified) would exhibit a similar performance under the same circumstances:

$$
\mathrm{E}\left(\mathrm{Y}_{1}-\mathrm{Y}_{0} \mid \mathrm{ISO}=1, X\right)=\left\{\mathrm{E}\left(\mathrm{Y}_{1} \mid \mathrm{ISO}=1, X\right)-\mathrm{E}\left(\mathrm{Y}_{1} \mid \mathrm{ISO}=0, X\right)\right\}-\left\{\mathrm{E}\left(\mathrm{Y}_{0} \mid \mathrm{ISO}=1, X\right)-\mathrm{E}\left(\mathrm{Y}_{0} \mid \mathrm{ISO}=0, X\right)\right\}(5)
$$

The second difference in equation (5) is the selection bias, which is assumed to be zero conditional on $X$. It represents the difference between the outcome of the certified firms, under the hypothetical circumstances that they had not been certified, and the outcome of uncertified firms in the same (and this time true) situation of no certification. If the selection bias represented by the second term is zero for given realizations of the vector $\boldsymbol{X}$, then we are left with only the causal effect. In other words, the performance difference between certified firms and the carefully selected group of control observations is a consistent estimate of the causal effect under the matching assumption.

The propensity score is the predicted probability of treatment, which in our case is the probability of firm $i$ obtaining ISO 9000 certification at time $t$. To obtain the propensity score, we estimate a probit model where explanatory variables include various firm characteristics at time $t$ $l$ (i.e., the year prior to certification), a dummy for firms operating in a services industry and a 
time trend. We include firm characteristics that, according to our exploratory regressions, matter for the likelihood of being certified in the future. The estimation results are presented in Appendix Table A2. They suggest that firms with larger sales, exports and profits are more likely to receive a certification. Firms in services are less likely to do so. More certifications appear to be awarded over time. $^{5}$

We use the nearest neighbor matching procedure and additionally restrict the control observations to those coming from within the same 2-digit NACE industry-year cell. Our matching procedure performs quite well. The average difference in propensity score between the matched observations is 0.003 . The test of the balancing hypothesis performed within blocks grouping observations with similar propensity score is satisfied. A simple t-test comparing the treated and the control group cannot reject the equality of means of exports, employment, labor productivity, profits, profitability, total labor cost and average wage prior to the treatment. Sales are an exception as the test suggests that future ISO recipients are slightly larger. See Appendix Table A3.

As unobservable heterogeneity, such as presence of a good manager or the geographic location, is likely to play a role in obtaining a certification, we apply the difference-in-differences approach to our matched sample. This means that we look for divergence in the performance paths of the certified firms and the matched control firms that had similar characteristics in the pre-certified year in the same industry and the same year. The performance analysis begins in the pre-certified period and focuses on the (cumulative) change in performance over the following year and then each of the subsequent three years. This allows us not only to comment on the magnitude of the

\footnotetext{
${ }^{5}$ The estimation sample excludes industries where no certifications were awarded during the period under study. These are: Fishing, Fish farming, and related service activities (NACE 5), Mining of uranium and thorium ores (NACE 12), Mining of metal ores (NACE 13), Manufacturing of tobacco products (NACE 16), Recycling (NACE 37), Water Transport (NACE 61), Air Transport (NACE 62), Insurance and pension funding, except compulsory social security (NACE 66), Renting of machinery and equipment without operator and of personal and household goods (NACE 71), Public administration and defense; compulsory social security (NACE 75), Activities of membership organizations n.e.c. (NACE 91).
} 
changes but also to analyze how soon these changes have taken place. This means, however, that we can focus only on firms who report the relevant variables in the year prior to being certified and in each of the three years following the certification. This leaves us with 234 certified firms.

\subsection{Sales}

The first variable we consider are total sales. We expect ISO recipients to see an increase in sales due to the ISO certification positively affecting their reputation as well as through the positive impact of the certification on productivity. The first two rows of Table 2 present the trajectory of sales among certified firms and the control group, respectively. In the pre-certification year, both groups exhibit a very similar level of sales. Both groups register a gradual increase in sales during the three years following the certification, but the sales increase faster among the treated (certified) firms. The difference (the average treatment effect on the treated, or the ATT) is positive and statistically significant at the five percent level already in the year when the certification was awarded. The size of the ATT increases over time as does its significance level. The magnitude of the effect is economically meaningful: an ISO 9000 certification boosts the recipients' sales by 45 percent by the third year following the certification. ${ }^{6}$

These findings are not surprising given than the ISO 9000 management system emphasizes a customer-focused principle and continuous quality improvement. Award of an ISO certification is likely to boost the recipient's sales because its signaling effect reduces information asymmetries between producers and customers. The immediate effect of a certification is also plausible because existing customers of a firm may be informed about the firm's preparations for the certification process.

\footnotetext{
${ }^{6}$ The magnitude of the effect equals $\mathrm{e}^{0.370}-1$.
} 
Table 2: Impact of an ISO 9000 Certification on Sales

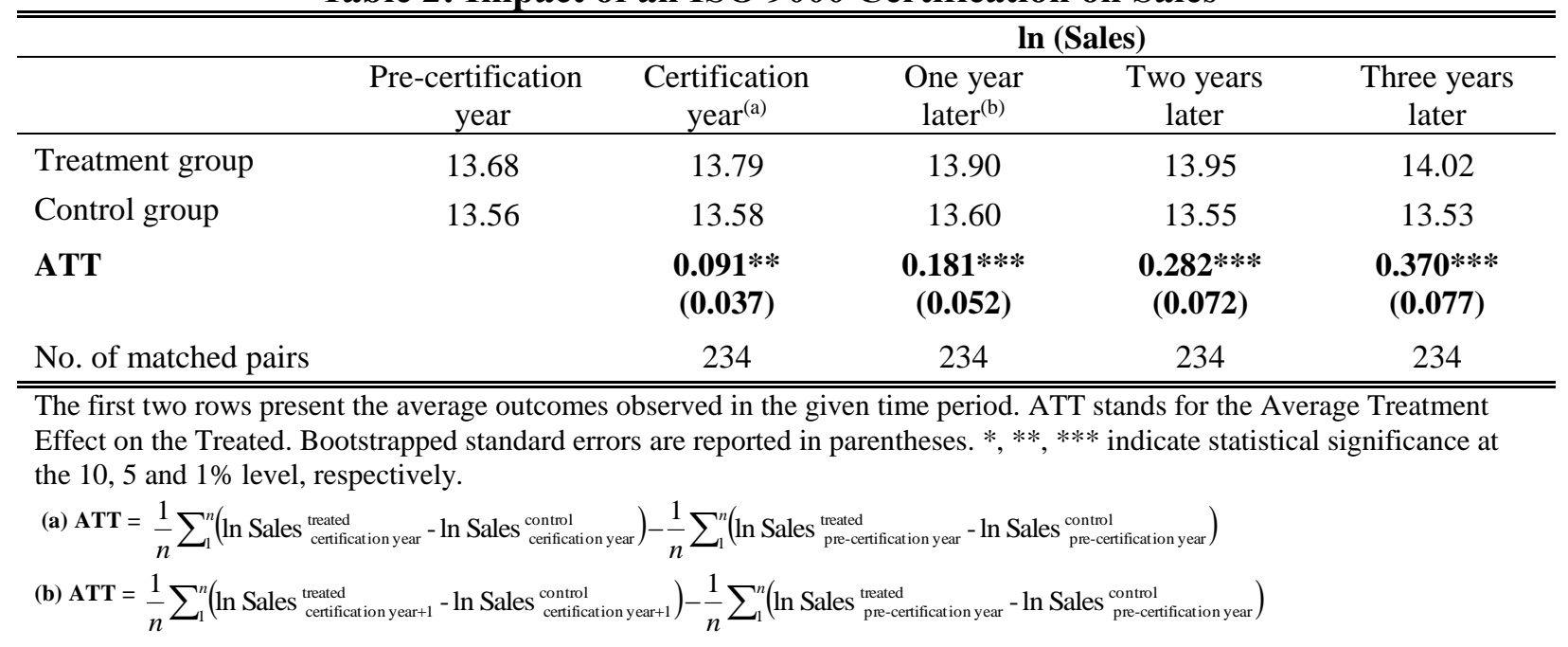

\subsection{Exports}

An award of an ISO certification is likely to affect exports more than domestic sales because information asymmetries tend to be more severe in international transactions. An ISO certification is recognized internationally as a signal of consistent quality of products and services of the certified firms to overseas partners. If consumers in foreign markets demand higher quality products relative to consumers in Slovenia, an ISO certification may boost the firm's exports by increasing its ability to produce products of a higher and/or consistent quality.

The results, presented in the top panel of Table 3 below, suggest that ISO recipients are more likely to export. The share of exporters in the treated group increases from $76.5 \%$ in the precertification year to $80.3 \%$ in the third year of being certified. The control group registers a decline in export participation from $77.4 \%$ to $73.5 \%$ in the same time period.

The results in the bottom panel of Table 3 are consistent with an ISO certification leading to improved export performance among existing exporters (hence, the smaller number of firms considered). In the pre-certification year, there is little difference in terms of the volume of exports between the treated and the control group. Over time, the treated firms increase their exports, while the control firms see a decline in their export performance. The difference between the two groups 
becomes statistically significant one year after the certification is awarded. An ISO certification seems to have a level effect. The certified firms see their exports boosted by 142 percent in the year following the certification, after which both their level of exports and the ATT remain roughly unchanged.

Table 3: Impact of an ISO 9000 Certification on Export Participation

\begin{tabular}{lccccc}
\hline \hline & & \multicolumn{4}{c}{ Exporter dummy } \\
& $\begin{array}{c}\text { Pre-certification } \\
\text { Year }\end{array}$ & $\begin{array}{c}\text { Certification } \\
\text { year }\end{array}$ & $\begin{array}{c}\text { One year } \\
\text { later }\end{array}$ & $\begin{array}{c}\text { Two years } \\
\text { later }\end{array}$ & $\begin{array}{c}\text { Three years } \\
\text { later }\end{array}$ \\
\hline Treatment group & 0.765 & 0.769 & 0.803 & 0.808 & 0.803 \\
Control group & 0.774 & 0.774 & 0.756 & 0.765 & 0.735 \\
ATT & & 0.0043 & $\mathbf{0 . 0 5 5 6}$ & $\mathbf{0 . 0 7 6 9 * *}$ & $\mathbf{0 . 0 7 6 9 * *}$ \\
& & $(0.025)$ & $\mathbf{( 0 . 0 3 4 )}$ & $\mathbf{( 0 . 0 3 1 )}$ & $(\mathbf{0 . 0 3 1 )}$ \\
No. of matched pairs & & 234 & 234 & 234 & 234 \\
\hline & & \multicolumn{4}{|c}{ ln (Exports) } \\
\hline Treatment group & 12.17 & 11.84 & 12.22 & 12.16 & 12.18 \\
Control group & 12.05 & 12.17 & 11.21 & 11.02 & 11.06 \\
ATT & & 0.177 & $\mathbf{0 . 8 8 3} * * *$ & $\mathbf{1 . 0 1 0} * * *$ & $\mathbf{0 . 9 9 4 * * *}$ \\
& & $(0.239)$ & $\mathbf{( 0 . 2 9 5 )}$ & $\mathbf{( 0 . 3 1 0 )}$ & $\mathbf{( 0 . 3 2 0 )}$ \\
No. of matched pairs & & 179 & 179 & 179 & 179 \\
\hline \hline
\end{tabular}

The first two rows in each panel present the average outcomes observed in the given time period. ATT stands for the Average

Treatment Effect on the Treated. Bootstrapped standard errors are reported in parentheses. *, **, *** indicate statistical significance at the 10,5 and $1 \%$ level, respectively.

\subsection{Employment}

So far we have documented that ISO recipients have registered a boost to their sales and exports. From the policy perspective, it is important to understand whether these changes have been accompanied by an increase in employment or whether the additional demand has been met by productivity improvements. It turns out that both factors have played a role.

The results in Table 4 show that on average certified firms have registered a steady increase in employment. In contrast, employment in the control group has remained flat. Certified firms saw a 5 percent higher employment growth already in the certification year. Three years later, the 
difference between the two groups reached 21 percent. In all years, the difference between the two groups was statistically significant at the one or the five percent level.

Table 4: Impact of an ISO 9000 Certification on Employment

\begin{tabular}{lccccc}
\hline \hline & & \multicolumn{4}{c}{$\ln ($ Employment) } \\
& $\begin{array}{l}\text { Pre-certification } \\
\text { Year }\end{array}$ & $\begin{array}{c}\text { Certification } \\
\text { year }\end{array}$ & $\begin{array}{c}\text { One year } \\
\text { later }\end{array}$ & $\begin{array}{c}\text { Two years } \\
\text { later }\end{array}$ & $\begin{array}{c}\text { Three years } \\
\text { later }\end{array}$ \\
\hline Treatment group & 4.16 & 4.23 & 4.28 & 4.31 & 4.32 \\
Control group & 4.08 & 4.10 & 4.09 & 4.08 & 4.04 \\
ATT & & $\mathbf{0 . 0 5 1} * *$ & $\mathbf{0 . 1 0 9} * * *$ & $\mathbf{0 . 1 5 1} * * *$ & $\mathbf{0 . 2 0 7 * * *}$ \\
& & $\mathbf{( 0 . 0 2 4 )}$ & $\mathbf{( 0 . 0 4 1 )}$ & $\mathbf{( 0 . 0 5 1 )}$ & $\mathbf{( 0 . 0 6 3 )}$ \\
No. of matched pairs & & 234 & 234 & 234 & 234 \\
\hline \hline
\end{tabular}

The first two rows present the average outcomes observed in the given time period. ATT stands for the Average Treatment Effect on the Treated. Bootstrapped standard errors are reported in parentheses. *, **, *** indicate statistical significance at the 10,5 and $1 \%$ level, respectively.

\subsection{Labor productivity}

Labor productivity is a commonly used proxy for efficiency with which firm uses factors of production. It is defined as the real value added per worker. Labor productivity may be affected by the ISO certification process in several ways. First, improved management practices, emphasis on preventive approach (in addition to a corrective action) for solving quality-related problems and continuous focus on quality improvement may lead to fewer defects in the final product and less rework necessary after inspection. They may allow firms to avoid adding value to defective products, which saves time and materials. All these factors are likely to increase the effectiveness of business operations, which will be reflected in labor productivity. Second, reputational benefits of an ISO certification may result in a larger scale of operations and translate into higher labor productivity. Third, opportunities to do business with world class companies arising thanks to the 
award of an ISO certification may benefit the recipient firms through productivity spillovers from the new customers (multinational firms operating in Slovenia or export partners abroad). ${ }^{7}$

ISO 9000 management system requires appropriate worker training and internalizing the eight management principles. Both processes may take time, therefore, it is reasonable to expect the benefits of a certification will manifest themselves with a lag.

The results of our analysis, reported in Table 5, are in line with an ISO certification boosting the labor productivity of the certified firms. While the certified firms see a continuous improvement in their labor productivity over time, the opposite trend is visible in the control group. The difference in performance between the two groups becomes statistically significant at the ten percent level three years after being certified. The magnitude of the effect is quite large: three years after being certified, the ISO recipients experience a 60 percent higher growth in labor productivity than the control group. ${ }^{8}$

Table 5: Impact of an ISO 9000 Certification on Labor Productivity

\begin{tabular}{lccccc}
\hline \hline & & \multicolumn{4}{c}{ In (Labor productivity) } \\
& $\begin{array}{c}\text { Pre-certification } \\
\text { Year }\end{array}$ & $\begin{array}{c}\text { Certification } \\
\text { year }\end{array}$ & $\begin{array}{c}\text { One year } \\
\text { later }\end{array}$ & $\begin{array}{c}\text { Two years } \\
\text { later }\end{array}$ & $\begin{array}{c}\text { Three years } \\
\text { later }\end{array}$ \\
\hline Treatment group & 8.22 & 8.29 & 8.38 & 8.41 & 8.47 \\
Control group & 8.34 & 8.25 & 8.35 & 8.18 & 8.12 \\
ATT & & 0.161 & 0.154 & 0.355 & $\mathbf{0 . 4 7 3}^{*}$ \\
& & $(0.189)$ & $(0.132)$ & $(0.246)$ & $\mathbf{( 0 . 2 4 9 )}$ \\
No. of matched pairs & & 234 & 234 & 234 & 234 \\
\hline \hline
\end{tabular}

The first two rows present the average outcomes observed in the given time period. ATT stands for the Average Treatment Effect on the Treated. Bootstrapped standard errors are reported in parentheses. *, **, *** indicate statistical significance at the 10,5 and $1 \%$ level, respectively.

\footnotetext{
${ }^{7}$ The recent literature (e.g., Trefler (2004)) has used labor productivity as a key firm-level outcome of interest. Although using total factor productivity might be preferable, computing it is much more demanding in terms of data requirements and thus would result in reducing the sample size.

${ }^{8}$ For comparison, Arnold and Javorcik (2009) who analyze the impact of foreign acquisitions on the labor productivity of acquired Indonesian plants find a 63 percent boost at $t+2$, which is slightly larger than the 43 percent effect found in the column labeled "two years later".
} 


\subsection{Average wage}

We expect improvements in labor productivity to be closely linked to increases in the average wage. There may be changes in labor composition (a shift towards more skilled or more motivated employees) and existing workers may be rewarded for better performance. ${ }^{9}$

The estimation results are consistent with our priors (see Table 6). Although both treated and control firms increase the average wage paid to their employees, the increase is larger among certified firms. The difference between the two groups becomes statistically significant at the ten percent level three years after being certified.

Table 6: Impact of an ISO 9000 Certification on the Average Wage

\begin{tabular}{lccccc}
\hline \hline & & \multicolumn{3}{c}{$\ln$ (Wage bill/Employment) } \\
& $\begin{array}{c}\text { Pre-certification } \\
\text { Year }\end{array}$ & $\begin{array}{c}\text { Certification } \\
\text { year }\end{array}$ & $\begin{array}{c}\text { One year } \\
\text { later }\end{array}$ & $\begin{array}{c}\text { Two years } \\
\text { later }\end{array}$ & $\begin{array}{c}\text { Three years } \\
\text { later }\end{array}$ \\
\hline Treatment group & 7.56 & 7.65 & 7.72 & 7.74 & 7.77 \\
Control group & 7.59 & 7.64 & 7.68 & 7.70 & 7.71 \\
ATT & & 0.036 & 0.061 & 0.065 & $\mathbf{0 . 0 7 8}^{*}$ \\
& & $(0.027)$ & $(0.041)$ & $(0.043)$ & $\mathbf{( 0 . 0 4 4 )}$ \\
No. of matched pairs & & 234 & 234 & 234 & 234 \\
\hline \hline
\end{tabular}

The first two rows present the average outcomes observed in the given time period. ATT stands for the Average Treatment Effect on the Treated. Bootstrapped standard errors are reported in parentheses. *, **, *** indicate statistical significance at the 10,5 and $1 \%$ level, respectively.

\subsection{Profits}

The ultimate reason why firms choose to invest time and financial resources into the certification process is to increase their profits. The certification process itself is costly, changes required for becoming certified may also require financial resources and their introduction may be disruptive. Thus it is likely becoming certified will not immediately lead to higher profits.

This is indeed the case in our data (see Table 7). We find that the average profits in the treated group increase in the certification year (relative to the year before), decrease slightly in the

\footnotetext{
${ }^{9}$ Unfortunately, we are unable to distinguish between skilled and unskilled workers in our data set.
} 
following year, only to register a big jump two years after certification. During the same time period, the control group experiences a steady decline in profitability, which is reversed only in the last year considered. The difference between the treated and the control group becomes statistically significant two years after certification. Our results are consistent with the certification having a positive, albeit delayed, level effect on profits.

Table 7: Impact of an ISO 9000 Certification on Profits

\begin{tabular}{lccccc}
\hline \hline & & \multicolumn{4}{c}{$\ln$ (Profits) } \\
& $\begin{array}{c}\text { Pre-certification } \\
\text { Year }\end{array}$ & $\begin{array}{c}\text { Certification } \\
\text { year }\end{array}$ & $\begin{array}{c}\text { One year } \\
\text { later }\end{array}$ & $\begin{array}{c}\text { Two years } \\
\text { later }\end{array}$ & $\begin{array}{c}\text { Three years } \\
\text { later }\end{array}$ \\
\hline Treatment group & 5.24 & 5.52 & 5.34 & 7.01 & 6.80 \\
Control group & 5.27 & 4.69 & 4.49 & 3.36 & 3.85 \\
ATT & & 0.858 & 0.871 & $\mathbf{3 . 6 7 3}^{* * *}$ & $\mathbf{2 . 9 7 5 * * *}$ \\
& & $(0.846)$ & $(0.890)$ & $\mathbf{( 0 . 8 8 2 )}$ & $\mathbf{( 1 . 0 4 6 )}$ \\
No. of matched pairs & & 234 & 234 & 234 & 234 \\
\hline \hline
\end{tabular}

The first two rows present the average outcomes observed in the given time period. ATT stands for the Average Treatment Effect on the Treated. Bootstrapped standard errors are reported in parentheses. *, **, *** indicate statistical significance at the 10,5 and $1 \%$ level, respectively.

\subsection{Profitability}

Higher profits may be due to a larger volume of sales, higher profitability or both. Thus it is interesting to consider profitability, defined as the ratio of profits to sales. Profitability improvement can be accomplished if an additional marginal increase in profits exceeds a marginal increase in sales.

Table 8: Impact of an ISO 9000 Certification on Profitability

\begin{tabular}{|c|c|c|c|c|c|}
\hline & \multirow[b]{2}{*}{$\begin{array}{c}\text { Pre-certification } \\
\text { Year }\end{array}$} & \multicolumn{4}{|c|}{ In (Profits/Sales) } \\
\hline & & $\begin{array}{c}\text { Certification } \\
\text { year }\end{array}$ & $\begin{array}{l}\text { One year } \\
\text { later }\end{array}$ & $\begin{array}{c}\text { Two years } \\
\text { later }\end{array}$ & $\begin{array}{c}\text { Three years } \\
\text { later }\end{array}$ \\
\hline Treatment group & 0.028 & 0.027 & 0.031 & 0.032 & 0.032 \\
\hline Control group & 0.021 & 0.020 & 0.023 & -0.002 & -0.017 \\
\hline ATT & & $\begin{array}{l}-0.0007 \\
(0.0092)\end{array}$ & $\begin{array}{c}0.0006 \\
(0.0120)\end{array}$ & $\begin{array}{l}0.0273 * \\
(0.0146)\end{array}$ & $\begin{array}{c}0.0420 * * * \\
(0.0151)\end{array}$ \\
\hline No. of matched pairs & & 234 & 234 & 234 & 234 \\
\hline
\end{tabular}

The first two rows present the average outcomes observed in the given time period. ATT stands for the Average Treatment Effect on the Treated. Bootstrapped standard errors are reported in parentheses. *, **, *** indicate statistical significance at the 10,5 and $1 \%$ level, respectively. 
The results in Table 8 suggest that certified firms see a slight, though gradual, increase in their profitability, while the control firms see a decline in their profitability. The ATT effect is statistically significant at the 10 percent level two years after the certification and at the one percent level in the following year. Thus the results are suggestive of the certification increasing the recipients' profitability, though this effect is not immediate.

\subsection{Channels}

As discussed earlier, obtaining an ISO 9000 certification may: (i) enhance the reputation of the recipient and thus lead to new or larger contracts with domestic and/or foreign partners; (ii) directly boost the recipient's performance thanks to implementation of the continuous improvement principle; (iii) improve the recipient's performance indirectly due to new (or more intense) business links with world class companies which result in new knowledge and additional pressure to improve performance.

The fact that we observe an immediate impact of the certification on sales and exports supports the view that a certification brings reputational benefits. The findings indicating the impact of a certification on labor productivity, profitability and average wage, which happen with a two to three year delay, are supportive on the continuous improvement channel. The large boost to exports experienced by the certified firms also makes the business links channel quite plausible.

One may wonder whether the efforts to obtain an ISO certification coincide with modernization of the production process. This does not seem to be the case. As visible in the Appendix Table A4, certified firms are not more likely to register a positive investment, increase their fixed assets or boost their capital intensity.

Instead, our results point towards improvements in management practices translating into better performance. This is consistent with the findings from a randomized controlled trial 
conducted by Bloom et al. (2013). These authors provided free management consulting to a set of randomly selected textile plants outside Mumbai to help them adopt modern management practices and compared the recipients' performance to another randomly chosen set of control plants. The experiment revealed that over several months as the firms slowly adopted modern management practices they experienced large increases in productivity.

One may be concerned about existence of time-varying firm-specific confounding factors, such as prospects of obtaining a lucrative contract whose timing coincides with the award of an ISO certification. Or a lucrative contract being conditional on obtaining an ISO certification. Our estimation strategy does not allow us to rule out such a possibility, but we draw comfort from the fact that some of the certification impacts take place with a three year delay, which make it unlikely that all of the effects would be due to a single contract.

\subsection{External validity}

One may be concerned about external validity of the results. Slovenia emerged as an independent state after the split of Yugoslavia in 1991, went through an economic transition and joined the European Union in 2004. Therefore, one may wonder whether the experience of Slovenian firms is informative for firms in other countries. We believe this is the case for two reasons.

First, given the requirements we impose in the matching procedure (i.e., that a firm must report the key variables in the year prior to obtaining a certification and for four years afterwards and that a suitable control firm exists), means that in practice our analysis focuses on ISO certifications awarded during the 1995-2002 period and outcomes pertaining to 1995-2005. Thus we will not be capturing the shock associated with the early years of Slovenian independence. It is also worth 
highlighting that we perform matching within industry-year cell, thus both the treated and the control observations are subject to the same shocks.

Second, we split the sample into two subperiods covering outcomes in 1995-97 vs 1998-2005 (see Appendix Table A4). This exercise indicates that our findings are not driven by observations from a particular sub-period, though given a much smaller sample size the results are less precisely estimated.

\section{Conclusions}

Policy makers around the world strive to find ways of boosting the economic growth of their countries. Our study suggests that importing state-of-the-art management practices may serve as a driver of productivity growth in emerging markets, particularly those which lag in this area.

Our analysis focuses on the effect of obtaining an ISO 9000 certification on firm performance. The ISO 9000 standard codifies international standards of best management practices and emphasizes quality assurance through preventive actions, process of continuous improvement and tracking customer satisfaction. While obtaining an ISO 9000 certification is costly in financial and management effort terms, it can help firms improve their performance, enhance their reputation and join global supply chains.

We analyze the effect of being ISO certified in the context of Slovenia, a transition country that due its socialist legacy lagged behind international standards in terms of management practices. To address the issue of firms self selecting to become certified our empirical analysis relies on propensity-score-matching combined with a difference-in-differences approach.

We indeed find that best performing firms self-select into receiving ISO certification. More importantly, we show that obtaining an ISO 9000 certification boosts the performance of certified firms in terms of sales, exports, labor productivity, profits, profitability, employment and wages. 
While most of these effects are felt almost immediately, the increase in labor productivity, profitability and wages takes place only after a few years.

A limitation of our study is that we are unable to determine whether the increase in the value of sales is driven by a larger quantity sold, higher quality (for instance, due to a lower number of faulty products per million or to increased product reliability) or a higher markup that ISO certified firms are able to charge. We hope that future research will be able to shed some light on this issue. 


\section{REFERENCES}

Arnold, Jens and Beata S. Javorcik, 2009. "Gifted Kids or Pushy Parents? Foreign Direct Investment and Plant Productivity in Indonesia" Journal of International Economics, 79(1), $42-53$

Arora, Ashish and Jai Asundi, 1999, "Quality Certification and the Economics of Contract Software Development: A Study of the Indian Software Industry" National Bureau of Economic Research, Working Paper 7260, July

Bertrand, Marianne and Antoinette Schoar 2003, "Managing with Style: The Effect of Managers on Firm Policies" Quarterly Journal of Economics, 118(4), 1169-1208

Blalock, Garrick and Paul J. Gertler, 2008. "Welfare Gains from Foreign Direct Investment through Technology Transfer to Local Suppliers" Journal of International Economics, 74(2), $402-421$

Bloom, Nicholas and John Van Reenen, 2007, "Measuring and Explaining Management Practices across Firms and Countries" Quarterly Journal of Economics, 122(4), 1357-1401

Bloom, Nicholas and John Van Reenen, 2010, "Why Do Management Practices Differ across Firms and Countries?” Journal of Economic Perspective, 24 (1), 203-224

Bloom, Nicholas, Benn Eifert, Aprajit Mahajan, David McKenzie and John Roberts, 2013, "Does Management Matter? Evidence from India" Quarterly Journal of Economics, 121: 1-51

Buttle, Francis, 1997, "ISO 9000: Marketing motivations and benefits" International Journal of Quality and Reliability Management, 14 (9), 936-947

Clougherty, J.A. and M. Grajek, 2008, "The Impact of ISO 9000 Diffusion on Trade and FDI: A New Institutional Analysis" Journal of International Business Studies, 39 (4), 613-633

Cole, Robert, 1999, Managing quality Fads, Oxford University Press, New York

Corbett, Charles J., María J. Montes-Sancho, and David A. Kirsch, 2005, "The Financial Impact of ISO 9000 Certification in the United States: An Empirical Analysis" Management Science, $51(7), 1046-1059$

De Loecker, Jan, 2007 "Do Exports Generate Higher Productivity? Evidence from Slovenia" Journal of International Economics, 73: 69-98

Guler, Isin, Mauro F. Guillen, and John Muir Macpherson, 2002, "Global Competitions, and the Diffusion of Organizational Practices: The International Spread of ISO 9000 Quality Certificates" Administrative Science Quarterly, 47 (2), 207-232

International Organization for Standardization (ISO), 2011, "The ISO Surveys of Certifications 2010" http://www.iso.org/iso/iso-survey2010.pdf, Geneva 
International Organization for Standardization (ISO), 2009, "The ISO Survey - 2008" http://www.iso.org/iso/survey2008.pdf , Geneva

International Organization for Standardization (ISO), 2001, "The ISO Survey of ISO 9000 and ISO 14000 Certificates - Tenth cycle" http://www.iso.org/iso/survey10thcycle.pdf, Geneva

Javorcik Beata S. 2004. "Does Foreign Direct Investment Increase the Productivity of Domestic Firms? In Search of Spillovers through Backward Linkages" American Economic Review, 94(3), 605-627

Javorcik, Beata S. and Mariana Spatareanu, 2008. "To Share or Not to Share: Does Local Participation Matter for Spillovers from FDI?” Journal of Development Economics, 85(1-2), 194-217

Javorcik, Beata S. and Mariana Spatareanu, 2009. "Tough Love: Do Czech Suppliers Learn from Their Relationships with Multinationals?" Scandinavian Journal of Economics, 85(1-2), 194217

Kim, S.J. and K.A. Reinert, 2009, "Standards and Institutional Capacity: An Examination of Trade in Food and Agricultural Products" International Trade Journal, 23 (1), 54-77

Svejnar, Jan, 2002, “Transition Economies: Performance and Challenges” Journal of Economic Perspectives, 16 (1), 3-28

Terlaak, Ann and Andrew A. King, 2006, "The effect of certification with the ISO 9000 Quality Management System Standard: A Signaling Approach” Journal of Economic Behavior and Organization, 60 (4), 579-602

Trefler, Daniel, 2004, "The Long and Short of the Canada-U.S. Free Trade Agreement" American Economic Review 94(4): 870-895

Van Biesebroeck, Johannes, 2005, "Exporting Raises Productivity in Sub-Saharan African Manufacturing Firms” Journal of International Economics, 67, 373-391 


\section{Appendix}

Table A1: Summary Statistics

\begin{tabular}{lcrr}
\hline \multicolumn{1}{c}{ Variables } & No. of obs. & \multicolumn{1}{c}{ Mean } & Std dev \\
\hline ISO certification dummy & 194,750 & 0.003 & 0.054 \\
ln (sales) & 194,750 & 10.252 & 2.204 \\
ln (exports) & 54,001 & 9.363 & 2.472 \\
Exporter dummy & 194,750 & 0.277 & 0.448 \\
ln (labor productivity) & 194,750 & 6.892 & 3.827 \\
ln (employment) & 194,750 & 1.545 & 1.110 \\
ln (average wage) & 194,750 & 7.061 & 1.045 \\
ln (profit) & 194,750 & 1.790 & 7.411 \\
ln (profitability) & 192,089 & -0.048 & 0.348 \\
$\ln$ (labor cost) & 194,750 & 8.599 & 1.800 \\
\hline
\end{tabular}

Table A2: Estimating Propensity Score

\begin{tabular}{|c|c|}
\hline $\ln ($ sales $\mathrm{t}-1)$ & $\begin{array}{l}0.085 * * * \\
(0.022)\end{array}$ \\
\hline $\ln ($ exports $\mathrm{t}-1)$ & $\begin{array}{l}0.020 * * * \\
(0.004)\end{array}$ \\
\hline $\ln ($ employment $t-1)$ & $\begin{array}{l}-0.109 * * \\
(0.055)\end{array}$ \\
\hline $\ln ($ total labor cost $t-1)$ & $\begin{array}{l}0.295 * * * \\
(0.052)\end{array}$ \\
\hline $\ln \left(\right.$ average wage $\left._{t-1}\right)$ & $\begin{array}{r}-0.023 \\
(0.050)\end{array}$ \\
\hline $\ln$ (labor productivity $\mathrm{t}-1$ ) & $\begin{array}{c}0.017 \\
(0.012)\end{array}$ \\
\hline $\ln \left(\right.$ profit $\left._{t-1}\right)$ & $\begin{array}{l}0.012 * * * \\
(0.003)\end{array}$ \\
\hline $\ln$ (profitability $\mathrm{t}-1$ ) & $\begin{array}{c}0.089 \\
(0.180)\end{array}$ \\
\hline Services sector & $\begin{array}{l}-0.242 * * * \\
(0.040)\end{array}$ \\
\hline Time trend & $\begin{array}{l}0.046 * * * \\
(0.009)\end{array}$ \\
\hline
\end{tabular}

No. of observations $\quad 151,723$

LR Chi ${ }^{2} \quad 1704.06$

Probability $>\mathrm{Chi}^{2} \quad 0.000$

Pseudo $\mathrm{R}^{2} \quad 0.2463$

Notes: Standard errors are reported in parentheses.

$*, * *, * * *$ indicate statistical significance at the 10,5 and $1 \%$ level, respectively. 
Table A3: Balancing Test

(t-test on the matched sample)

\begin{tabular}{lccccc}
\hline & $\begin{array}{l}\text { Mean } \\
\text { Treated }\end{array}$ & $\begin{array}{l}\text { Mean } \\
\text { Control }\end{array}$ & t-test & p-value & No. of obs. \\
& 13.680 & 13.560 & -2.2330 & 0.0265 & 234 \\
$\ln \left(\right.$ sales $_{\mathrm{t}-1)}$ & 12.175 & 12.048 & -0.7589 & 0.4489 & 179 \\
$\ln \left(\right.$ exports $\left._{\mathrm{t}-1}\right)$ & 4.157 & 4.079 & -1.1668 & 0.2445 & 234 \\
$\ln \left(\right.$ employment $\left._{\mathrm{t}-1}\right)$ & 7.561 & 7.587 & 0.5887 & 0.5566 & 234 \\
$\ln \left(\right.$ average wage $\left._{\mathrm{t}-1}\right)$ & 8.222 & 8.343 & 1.0692 & 0.2861 & 234 \\
$\ln (\text { labor productivity } \mathrm{t}-1)^{\ln \left(\text { profit }_{\mathrm{t}-1}\right)}$ & 5.242 & 5.266 & 0.0315 & 0.9749 & 234 \\
$\ln \left(\right.$ profitability $\left._{\mathrm{t}-1}\right)$ & 0.028 & 0.021 & -0.8593 & 0.3911 & 234 \\
\hline
\end{tabular}

Note: The number of observations for exports is smaller as non-exporters drop out from the sample due to logs being taken.

Table A4: Impact of an ISO 9000 Certification on Investment and Capital Intensity

\begin{tabular}{|c|c|c|c|c|c|}
\hline & \multicolumn{5}{|c|}{ Positive investment (indicator variable) } \\
\hline & $\begin{array}{c}\text { Pre-certification } \\
\text { year }\end{array}$ & $\begin{array}{c}\text { Certification } \\
\text { year }\end{array}$ & $\begin{array}{c}\text { One year } \\
\text { later }\end{array}$ & $\begin{array}{c}\text { Two years } \\
\text { later }\end{array}$ & $\begin{array}{c}\text { Three years } \\
\text { later }\end{array}$ \\
\hline Treatment group & 0.500 & 0.671 & 0.658 & 0.560 & 0.517 \\
\hline Control group & 0.427 & 0.573 & 0.534 & 0.543 & 0.453 \\
\hline ATT & & $\begin{array}{c}0.026 \\
(0.058)\end{array}$ & $\begin{array}{c}0.051 \\
(0.069)\end{array}$ & $\begin{array}{l}-0.056 \\
(0.045)\end{array}$ & $\begin{array}{l}-0.009 \\
(0.070)\end{array}$ \\
\hline \multirow[t]{3}{*}{ No. of matched pairs } & & 234 & 234 & 234 & 234 \\
\hline & \multicolumn{5}{|c|}{ In (Change in Fixed Assets) } \\
\hline & $\begin{array}{c}\text { Pre-certification } \\
\text { year }\end{array}$ & $\begin{array}{c}\text { Certification } \\
\text { year }^{(a)}\end{array}$ & $\begin{array}{c}\text { One year } \\
\text { later }^{(b)}\end{array}$ & $\begin{array}{c}\text { Two years } \\
\text { later }\end{array}$ & $\begin{array}{c}\text { Three years } \\
\text { later }\end{array}$ \\
\hline Treatment group & 2.89 & 2.89 & 3.51 & 2.52 & 0.526 \\
\hline Control group & 0.88 & 1.91 & 1.43 & 1.10 & -1.70 \\
\hline ATT & & $\begin{array}{l}-0.185 \\
(1.429)\end{array}$ & $\begin{array}{c}0.070 \\
(1.402)\end{array}$ & $\begin{array}{l}-0.596 \\
(1.302)\end{array}$ & $\begin{array}{c}0.217 \\
(1.740)\end{array}$ \\
\hline \multirow[t]{3}{*}{ No. of matched pairs } & & 184 & 184 & 184 & 184 \\
\hline & \multicolumn{5}{|c|}{ In (Fixed Assets/Employment) } \\
\hline & $\begin{array}{c}\text { Pre-certification } \\
\text { year }\end{array}$ & $\begin{array}{c}\text { Certification } \\
\text { year }^{(\mathrm{a})}\end{array}$ & $\begin{array}{c}\text { One year } \\
\text { later }^{(b)}\end{array}$ & $\begin{array}{c}\text { Two years } \\
\text { later }\end{array}$ & $\begin{array}{c}\text { Three years } \\
\text { later }\end{array}$ \\
\hline Treatment group & 8.40 & 8.54 & 8.62 & 8.65 & 8.69 \\
\hline Control group & 8.40 & 8.52 & 8.63 & 8.74 & 8.80 \\
\hline ATT & & $\begin{array}{l}0.0197 \\
(0.060)\end{array}$ & $\begin{array}{r}-0.0157 \\
(0.085)\end{array}$ & $\begin{array}{l}-0.0904 \\
(0.072)\end{array}$ & $\begin{array}{c}-0.1146 \\
(0.087)\end{array}$ \\
\hline No. of matched pairs & & 234 & 234 & 234 & 234 \\
\hline
\end{tabular}


Table A5: Impact of an ISO 9000 Certification on Firm Outcomes: Considering Two Sub-periods

\begin{tabular}{|c|c|c|c|c|c|c|c|c|}
\hline & \multicolumn{4}{|c|}{ Until 1997} & \multirow[b]{2}{*}{$\begin{array}{c}\text { Certification } \\
\text { year }\end{array}$} & \multicolumn{3}{|c|}{ From 1998 on } \\
\hline & $\begin{array}{c}\text { Certification } \\
\text { year }\end{array}$ & One year later & $\begin{array}{c}\text { Two years } \\
\text { later }\end{array}$ & $\begin{array}{c}\text { Three years } \\
\text { later }\end{array}$ & & One year later & $\begin{array}{c}\text { Two years } \\
\text { later }\end{array}$ & $\begin{array}{c}\text { Three years } \\
\text { later }\end{array}$ \\
\hline $\ln$ (Sales) & $\begin{array}{c}0.030 \\
(0.048)\end{array}$ & $\begin{array}{c}0.078 \\
(0.063)\end{array}$ & $\begin{array}{l}0.145^{*} \\
(0.078)\end{array}$ & $\begin{array}{c}0.291 * * \\
(0.114)\end{array}$ & $\begin{array}{l}0.110 * * \\
(0.050)\end{array}$ & $\begin{array}{l}0.210 * * * \\
(0.055)\end{array}$ & $\begin{array}{c}0.308 * * * \\
(0.080)\end{array}$ & $\begin{array}{c}0.392 * * * \\
(0.090)\end{array}$ \\
\hline No. of matched pairs & 81 & 81 & 81 & 81 & 153 & 153 & 153 & 153 \\
\hline Exporter dummy & $\begin{array}{l}0.0123 \\
(0.035)\end{array}$ & $\begin{array}{l}0.0370 \\
(0.034)\end{array}$ & $\begin{array}{c}0.0741 * \\
(0.043)\end{array}$ & $\begin{array}{l}0.0494 \\
(0.043)\end{array}$ & $\begin{array}{c}0.000 \\
(0.032)\end{array}$ & $\begin{array}{l}0.072 * \\
(0.040)\end{array}$ & $\begin{array}{l}0.092 * \\
(0.050)\end{array}$ & $\begin{array}{l}0.092 * \\
(0.051)\end{array}$ \\
\hline No. of matched pairs & 81 & 81 & 81 & 81 & 153 & 153 & 153 & 153 \\
\hline $\ln$ (Exports) & $\begin{array}{c}0.200 \\
(0.381)\end{array}$ & $\begin{array}{c}0.504 \\
(0.416)\end{array}$ & $\begin{array}{c}0.614 \\
(0.507)\end{array}$ & $\begin{array}{c}0.724 \\
(0.452)\end{array}$ & $\begin{array}{c}0.066 \\
(0.358)\end{array}$ & $\begin{array}{l}1.093 * * \\
(0.514)\end{array}$ & $\begin{array}{l}1.178 * * * \\
(0.433)\end{array}$ & $\begin{array}{l}1.012 * * \\
(0.458)\end{array}$ \\
\hline No. of matched pairs & 71 & 71 & 71 & 71 & 108 & 108 & 108 & 108 \\
\hline ln (Employment) & $\begin{array}{l}-0.004 \\
(0.040)\end{array}$ & $\begin{array}{c}0.046 \\
(0.060)\end{array}$ & $\begin{array}{c}0.054 \\
(0.072)\end{array}$ & $\begin{array}{c}0.101 \\
(0.095)\end{array}$ & $\begin{array}{c}0.076 * * * \\
(0.029)\end{array}$ & $\begin{array}{l}0.141 * * * \\
(0.039)\end{array}$ & $\begin{array}{c}0.176 * * * \\
(0.043)\end{array}$ & $\begin{array}{c}0.241 * * * \\
(0.067)\end{array}$ \\
\hline No. of matched pairs & 81 & 81 & 81 & 81 & 153 & 153 & 153 & 153 \\
\hline ln (Labor productivity) & $\begin{array}{l}-0.019 \\
(0.125)\end{array}$ & $\begin{array}{c}0.083 \\
(0.261)\end{array}$ & $\begin{array}{c}0.486 \\
(0.497)\end{array}$ & $\begin{array}{c}0.538 \\
(0.417)\end{array}$ & $\begin{array}{c}0.253 \\
(0.227)\end{array}$ & $\begin{array}{c}0.180 \\
(0.139)\end{array}$ & $\begin{array}{l}0.387 * \\
(0.216)\end{array}$ & $\begin{array}{c}0.548 * * \\
(0.229)\end{array}$ \\
\hline No. of matched pairs & 81 & 81 & 81 & 81 & 153 & 153 & 153 & 153 \\
\hline $\begin{array}{l}\text { In (Wage } \\
\text { bill/Employment) }\end{array}$ & $\begin{array}{c}0.014 \\
(0.030)\end{array}$ & $\begin{array}{l}0.015 \\
(0.037)\end{array}$ & $\begin{array}{c}0.014 \\
(0.052)\end{array}$ & $\begin{array}{c}0.052 \\
(0.052)\end{array}$ & $\begin{array}{c}0.045 \\
(0.037)\end{array}$ & $\begin{array}{c}0.078 \\
(0.053)\end{array}$ & $\begin{array}{c}0.088 \\
(0.058)\end{array}$ & $\begin{array}{c}0.089 \\
(0.056)\end{array}$ \\
\hline No. of matched pairs & 81 & 81 & 81 & 81 & 153 & 153 & 153 & 153 \\
\hline $\ln$ (Profits) & $\begin{array}{c}1.397 \\
(1.372)\end{array}$ & $\begin{array}{c}0.960 \\
(1.613)\end{array}$ & $\begin{array}{c}6.794 * * * \\
(2.080)\end{array}$ & $\begin{array}{c}6.739 * * * \\
(2.048)\end{array}$ & $\begin{array}{c}0.268 \\
(1.064)\end{array}$ & $\begin{array}{c}0.030 \\
(1.158)\end{array}$ & $\begin{array}{c}2.493 * * * \\
(0.926)\end{array}$ & $\begin{array}{c}1.249 \\
(1.252)\end{array}$ \\
\hline No. of matched pairs & 81 & 81 & 81 & 81 & 153 & 153 & 153 & 153 \\
\hline ln (Profits/Sales) & $\begin{array}{c}0.0030 \\
(0.0112)\end{array}$ & $\begin{array}{c}0.0119 \\
(0.0159)\end{array}$ & $\begin{array}{c}0.0560 * * * \\
(0.0192)\end{array}$ & $\begin{array}{c}0.0900 * * * \\
(0.0330)\end{array}$ & $\begin{array}{l}-0.0027 \\
(0.0119)\end{array}$ & $\begin{array}{l}-0.0068 \\
(0.0170)\end{array}$ & $\begin{array}{c}0.0116 \\
(0.0199)\end{array}$ & $\begin{array}{c}0.0206 \\
(0.0216)\end{array}$ \\
\hline No. of matched pairs & 81 & 81 & 81 & 81 & 153 & 153 & 153 & 153 \\
\hline
\end{tabular}

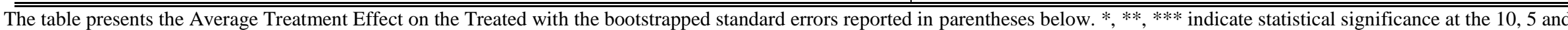
$1 \%$ level, respectively. 